\title{
A Journey of Exploration and Reconstruction of the Feminine Self: Reading Shivya Nath's The Shooting Star: A Girl, Her Backpack and the World (2018)
}

\author{
Akshita Chotia \\ Research Scholar, Department of English and Modern European Languages, Banasthali \\ University, Rajasthan.Email: akshitasharmaoo23@gmail.com
}

\begin{abstract}
The contemporary philosophical, intellectual and literary plentitudes aver the fact that travel literature deals with the discourse of identity. Travel records our temporal and spatial progress. It throws light on how one is defined and identified. Many critical texts on travel writing have explored the transcendental world of the journey of the human self. Further, there have been some critical theorists from India as well who have also examined the uncanny nature of journey and therefore the journey in the outside world is represented as a metaphor of the journey of the internal world. In addition, there have been some Indian women writers who have explored the complex terrain of journey that a woman undertakes and through the process they explore themselves. The present paper intends to explore the journey from an existential crisis to the growth of the woman self in the book The Shooting Star: A Girl, Her Backpack and the World (2018) by Shivya Nath. The vivid descriptions, moving encounters and the uplifting adventures of an Indian woman which are depicted in the book, map not only the world but also the human spirit. The study intends to apply the basic arguments of female bildungsroman and theory of self for understanding the process of growth and development as far as the life of the protagonist is concerned.
\end{abstract}

Keywords: identity crisis, exploration of the woman self, female bildungsroman, travel literature.

"The real voyage of discovery consists not in seeking new landscapes but in having new eyes" -Marcel Proust

The ontological and epistemological knowledge tradition have found out the postmodern world, fragmented and disruptive. The postmodern self and subject, therefore is directed towards "modern narratives that would otherwise maintain a unitary understanding of self and other in society." (Westgate, 2009, p.774) Without having any story to trust upon which has been documented in history, many individuals left their space to make their own room to explore the world with reference of their personal narratives. Through their narratives, they further uncover their existence and expectations regarding who they are and what they want to become. Travel narratives have been affecting women's identity and ideology in a positive manner to explore their idea of self. Shivya Nath's travelogue The Shooting Star: A Girl, Her Backpack and the World (2018) vividly portrays the ideological concepts which serve as a biological catalyst for exploring, confronting and reconstructing her own identity. In the beginning, Shivya Nath recognizes that, at the age of twenty- three, her life is not running the way it should and she is not even aware of

(C) AesthetixMS 2020. This Open Access article is published under a Creative Commons Attribution Non-Commercial 4.o International License (http://creativecommons.org/licenses/by-nc/4.o/), which permits non-commercial re-use, distribution, and reproduction in any medium, provided the original work is properly cited. For citation use the DOI. For commercial re-use, please contact editor@rupkatha.com. 
what is happening around her. She has always been under the patriarchal rule and she has grown up in the similar way where girls were not allowed to do what they actually want to do. This is how she expresses her predicament:

When some of my more adventurous friends from school got together to hike or drive their bikes up to nearby hill towns, I didn't get permission to leave home. If a longing to explore the world that lay beyond was within me then, it remained buried under a heap of fear, insecurity and paranoia that I had imbibed at home. (Nath, 2018, p. 21)

The restriction imposed on a woman about going out of her home turned up as a catalyst to stimulate her repressed desires. It convinced her to reformulate her genuine self and taught her to accomplish bliss in life. Religious, cultural and socio- political tenets provided her the possibility to answer inward questions: "It seemed as though I had fallen into a mould, and this mould had become comfort zone Even though I felt the urge to break away, I remained within it, not knowing how to break it." (Nath, 2018, p. 23)This inward journey provided her the chance to tackle identity crisis. She started finding peace and joy in the construction of her own new self.

This article explores the narrative The Shooting Star in the light of postmodernism, most specifically the third wave feminism which enlightened women to find their lost selves. It also delineates how women confront and reconstruct their selves in response to the distortion of their identity by male-centric society beyond time and space. It has its foundation in dominant features of travel literature and its impact on human beings as subject, which reveals the role of exploration of self in the life of a woman. The study will progress by exploring the ideological concept of the female bildungsroman for the better understanding of historical and cultural contexts under which Nath's text The Shooting Star was created.

Explaining the governing principles of postmodernism is quite a challenging task, because the foremost aim of postmodernism is to destabilize the dominant patriarchal beliefs entrenched in society and rejecting the set definitions which lead towards gender inequality. Postmodernism escalates the idea of what being a female means. According to Judith Butler (1990) it "enables a reconceptualizing of identity and a deconstruction of the universal category "woman." Postmodernism discusses the ideals of individuality, advocating the idea of multiplicity of truth, fragmentation of self and the argument for point of view. The process of learning is easy as compared to the process of unlearning. It is in the realm of unknowingness that sometimes one may find the purpose of life. The restrictions and the obstacles, contrary views, and existence of opposition will always be there; after all tradition of knowledge in itself is dialectical in nature. The fear of anti-thesis which may break the conventional understanding, and thus leave one in ambiguity works as a barrier to the thought of exploring and testing one's own limits. But it is here in the acid test that the process of unbecoming takes place, as whatever she had learned which confined her, made her a victim at the hands of ISAs and RSAs. They were all a part of her process of becoming and now that she accepts she has much to learn, that is where her process of unbecoming begins.

Unbeknownst to me, it had become my mission to prove that the world isn't the horrible place we often make it out to be. That just because there are some dirty fish, it doesn't mean the entire ocean is dirty and we need to confine ourselves to the shores we know. The fear bred by the news compels people to stay at home - trapped in a shrinking comfort zone - like it had once compelled me. I had much to unlearn for the sake of the freedom I chased, the victimhood I despised and my mission to build unlikely friendships. (Nath, 2018, p. 79) 
Some empirical, cognitive, and pragmatic studies have represented the fact that self, subject and subjectivity are observed differently as far as the realities of the male and female are concerned. Some advocates of Historical Feminism, Womanism, and Gender Studies have established the fact that the process of the constitution of a woman's self is different from that of a male's self. However, without being caught into the imbroglio of the binary between the male and female or man and woman, we can say that the self of a woman is constructed, controlled, and hegemonized by the monological self of the patriarchy. By bringing sex and gender into the spectrum of self and subject, one can understand that the sexual realities entail in a different way upon different sexes. Carol Lazzaro-Weis (1993) in her book From Margins to Mainstream: Feminism and Fictional Modes in Italian Women's Writings 1968-1990 states that, "A theory of experience allows a woman to contemplate how we place ourselves or are placed in social reality, and what constitutes that which we perceive as subject." (qtd. in Reich, 1996, p. 128) As per the received historical accounts one may recount the fact that individuals of male and female sex perceive and inhabit the world in a different manner. The world of the female is defined, shaped and reshaped by power structure along with the oppressive order of patriarchy. This dominant patriarchy can be seen throughout her journey. Hence, The Shooting Star provides in-depth exploration of the woman self with the detailed journey of the character's personal narrative. Nath asserts:

The desire of travelling solo had perhaps sprung out of the inherent frustration of growing up as a sheltered girl in India. One who couldn't even take control of her own life. One who always needed a man to protect her. One who, even after becoming financially independent, needed to rely on others to make her own decisions.(Nath, p. 72)

The empiricist, cognitive/ rationalist and the pragmatic models of feminism suggest that "one is not born, but becomes a woman. No biological, psychological, or economic fate determines the figure that the human female presents in society: it is civilization as a whole that product this creature, feminine" (p. 249) ascribes Simone de Beauvior's The Second Sex (1952). Judith Butler's Gender Trouble: Feminism and the Subversion of Identity (1990) conducts a genealogical inquiry to establish the fact that gender is not innate and inherent feature of human nature but it is a consequence of cultural performances. Similarly, John Stuart Mill's The Subjection of Women (1869) puts stress not only for the economic rights of women but also for their political rights. The aforesaid thinkers and writers have examined the construction and subjugation of the women self. In the process of subjection, the woman is circumscribed within the texture of socio-pragmatic realities of the world. The woman protagonist is finally doomed to failure and is never allowed to attain maturity. But the contemporary phenomenon of Feminism, postmodernism, third wave feminism and the present study do not look into the subjugation of women but they try to identify the possible methods through which a liberated self of women can be constituted. The liberation of women self focuses on the idea of the female bildungsroman. It stands in a deferral and dialectical relations to classical bildungsroman. It explores the development of the bildung through the indispensable integration into epistemic structure and societal environment. Female bildung aims at deconstructing traditional notions of selfcultivation to produce an alternative trajectory of female development. The character gradually attains the liberation and reconstructs a new identity and attains the growth in her character through every step she takes by breaking the patriarchal rule. As the protagonist in The Shooting Star asserts:

Growing up as a sheltered girl in India had propelled me into unexpected battles. The battle with my loving family before my first solo sojourn to Spiti was really a fight to take 
control of my adult life. When I was hiking in those mountains and lying under a million stars, I had felt responsible for my own decisions for the first time; I had felt capable and wise and liberated for the first time, and I had loved the 'me' I was becoming. (Nath, p. 72)

Feminists of all the phases and of all geographical regions have accounted for the fact that the female constructs her bildung in completely different way because cultural, linguistic, economic and social factors act differently upon her consciousness, hence she may experience a different possibility of her self- cultivation or self- acculturation. Fraiman in her Voyage In: Fictions in Female Development (1993) espouses for an alternative generic mode which may record the uneven development of the female bildung. The narrative of female bildung not only focuses on the growth of the character but also records the thematic of her growing up and growing down, her sacrifice, madness and death. Githa Hariharan in her When Dreams Travel (2008) explains how woman can get empowerment through travelling and experience the growth and development of her character. She has used travel as a tool by which women can explore herself and her inner quest. The moment she stepped out for once by breaking the patriarchal rules, she felt far more liberated then she was earlier:

I was unknowingly stepping down from society's pedestal for women and breaking away

from the mould I had been groomed for. Perhaps I was a fool, but I felt like I was becoming a liberated fool. (Nath, p.73)

The struggle of women leads them towards identity. To find identity they struggle a lot. The amount of struggle they experience is because at every moment they feel crisis and conflict. The crisis and conflict bring the women into the texture of alienation and some kind of angst and anger. All these major strophes are related to the philosophy of Existentialism. Therefore, this growth and development of woman self in travel writings can better be understood through her existential struggle. Existentialism as a school of thought provides human beings with philosophical, theoretical and critical ideas and thoughts to cope up with the meaninglessness, purposelessness, rootlessness, anxiety, and angst of our lives. In other words, it helps one to survive even in the most difficult times. "We tend to ask existential questions about happiness only when we are at our most miserable." (Nath, p. 30). On the one hand the Bildungsheld are in the process of becoming matured, but on the other they appear to have been struggling to exist and to transcend the boundary of the pragmatic world. This struggle brings them to the world of existential problems; however, towards the end of the journey of their life, the female characters transcend those problems.

At the beginning of the book, Shivya Nath quits her corporate job at the age of twenty - three to travel the world. She is eager to change her life and for the attainment of an authentic happiness, she gave up her home, sold most of her possessions and headed off on a nomadic travel allocated on the cover as "A Girl, Her Backpack and the World"(Nath, 2018). The book begins where she feels the depth of emptiness and finds her consciousness filled with despair and hopelessness. A moment comes where she is not able to express why she wants to travel or what kind of madness she has inside her own self. It is here that the reader recognizes the causes of her constraint and looks at the confrontation her own self:

I woke up to a barrage of questions, of which I had answers to the easy one: are those roads safe enough to travel, and what is the point of this trip? Where will we find you if you go missing, and do you know what it is like to travel alone as a young woman in India? Battling my inner demons to reconfigure my direction in life promised to be easier than battling my family's inhibitions. How could I explain in words my craving for freedom, that longing for anonymity, the need to distance myself from everything I knew 
in my universe... that there was no reason behind this 'madness' other than madness itself? (Nath, p.26)

By affirming the expectancies that she should have a "settled job" and a "properly refined house" by now, the writer is visibly insinuating and resisting with the motionless viewpoint of the woman self that the second wave struggled to disassemble and postmodern ideas deconstructed it. Till the age of twenty-three, she neither has a good job nor a nice house and moreover she is on an inward travel to explore an authentic identical self in her life. The writer is truly the living embodiment of the "self-determined and self-possessed" third wave subject. According to Foss and Foss (2011), her self- reflection was spinning towards the emblematic sources of her mind to recognize her own place in the world. Simply put, it is in her admittance to what she is not, and throughout the story that she transforms and reconstructs herself for becoming a better version of her own self. Through the selection of her own conceptions, contemplation, elucidation, and her proceedings, Shivya Nath is epitomizing what Foss and Foss' (2011) explain "as a key strategy for change in their paradigm of constructed potentiality, which asserts that if individuals are experiencing negative feelings as a result of an exigence they choose to perceive, the strategy of interpretation can be used to make another choice about what to perceive, how to interpret that perception, and how to frame that interpretation symbolically to transform those feelings" (p. 215). Here, Shivya Nath seeks to locate her knowledge, to survive differently from within, and herself in the emergent circumstances.

Here, Shivya Nath is admitting the accountability and trying to engage her identifiable competence to "choose her thoughts," and trying to reframe her proficiencies from "curses" into "opportunities."Alice Walker stated, "though life as we know it has fallen into the pit, each of us has the knowledge of how to live life differently that no one taught us, and that we can find this knowledge and put it to use." (2006, p. 42) With the process, Shivya Nath tries to uncover the existing awareness regarding how to survive in a different manner with the new elucidations of her own self and the conditions. The way her journey progresses, she clearly visualizes what she was and how travelling helped her to create her own authentic identity. Here, she asserts, "when I look back at my own journey now, I can clearly visualize the person I was before the sabbatical and after it." (Nath, p.25)

Shivya Nath's crisis for existence impelled her to confront and reconstruct her former self which was provided to her by the family in which she has grown up and as an outcome she sets out on a solo travel to reconstruct a more authentic identity. As the narrative progresses one observes how she travels from an existential crisis towards the attainment of the maturity of an authentic and liberated self. Here two important premises which enlighten how the woman self is practiced through the vehicle of travel, postmodern idea and female bildungsroman need to be mentioned. First, the main theme spins around the course of confronting and surpassing the self with which the protagonist struggles to explore the inner conflict of the crisis of identity. Second, she focuses on the reconstruction of a new self by connecting her existing self with a new awareness. She gains this new awareness through travelling and by connecting to new people she understands "universal identity" which encompasses all individual subjects. In both the themes, small narratives work as a vehicle for the exploration of the new self.

The female character in The Shooting Star is constantly on move and hence she is perpetually becoming and unbecoming. This infinite process of epistemological construction can aptly be seen in travel writings as the characters are always on move and keep receiving innumerable impressions and experience in life. In his book Travel Writing (2011), Carl Thompson states that, "Travel is one of the greatest doors to freedom and travel book is a medium through 
which human celebrates this freedom. To travel is to make a journey, a movement through space. Travel is the negotiation between self and other that is brought about by movement of space." (Thompson, 2011, p.9) Though travel writing intends to explore the alterity of the self yet it is different as far as the gender choices are concerned. The travel writings documented by some male writers represent a different kind of exploration of the self than the quest of self in women's travel writings.

Women have always journeyed more comprehensively than men. In "American Women and Travel Writing" Susan L. Roberson argues that "patriarchy created a social map that constructed some spaces as feminine and others as masculine using gender difference to inscribe spatial difference." (2009, p. 217). The gendering of travel has existed since time immemorial. In many cultures, periods and societies, the restlessness, freedom of travel and taste for explorations and adventures have been featured as the prerogatives of men rather than women. But the received information about the gendering of travel is an ideological construct that assumes and stimulates the conception of discrete spheres for men and women. Some travelling women have created an immense frame of travel writings. They mainly travel to explore the inner self and to create their own identity. In The Shooting Star the narrator travels in a different way and says, "I am a descendant of someone who once moved with all her possessions, without a permanent roof above her head. I am a nomad." (Nath, p. 107) The liberty of travel associated with other freedom and identity renovations become harbingers of social change. The character gradually attains the liberation and reconstructs a new identity and attains the growth in her character through her every step she takes by breaking the patriarchal rule:

I remember the years I had been too afraid to dream of sitting on the ledge of a humble yellow house, chatting with a family that wasn't my own, chatting in a language that wasn't my own, in a part of the world so far away from the one I grew up in and yet not that different. (Nath, p. 66).

The lines explain for the female predicament, that even a dream to be at some place other than home was accompanied with a sense of fear and anxiety. As if to talk to the strangers, to be in a place not known to us was forbidden. People made it sound so different, but possibly it was not so different to begin with. It expresses the longing desire of freedom to be like a free bird, which known no boundaries and any discrimination. It is a free soul which travels with all harmony and peace and grows and matures with experience. The possibilities for the exploration of the woman self and identity were very limited former to the third wave feminism. Due to the voice raised for equal opportunities and with the arrival of birth control pills during second wave feminist movement, women are now free to hold-up their motherhood, their preferred career and look for their own self beyond the boundaries of mother and wife. The former aim of second wave feminism, as Kearney (1979) expounds, "focused primarily on needed social structural changes and did not emphasize change in sex roles on an interpersonal level." (1979, p. 28) These issues are well taken up by the third wave feminists. According to them women are responsible to and for themselves, not representative of and thus beholden to generations of women past, present, and future. Likewise M. Hammers (2005) describes that, "change is directed at the level of the individual experience and now woman self is empowered to reconstruct their own subjective meanings about the world." (p. 171)

Arthur Frank (1995) claims, "in stories, the teller not only recovers her voice; she becomes a witness to the conditions that rob others of their voices...when any person recovers his voice, many people begin to speak through that story." (p. 12) A similar conception is been reconnoitred by Gloria Anzaldúa, once she recommended that one must "imagine the text as altar-as an 
interactive site of healing that is remade through each loving encounter with readers over time and across space-invit[ing] us to engage as readers and writers with one another within the register of the sacred." (qtd. in Carrillo Rowe, 2009, p. 18) In the process of partaking her own version, Nath constructs a platform which can heal other women by going through her journey of self- exploration.

\section{Conclusion}

The Shooting Star thus uncovers the way how a female encounters her conflicting self underneath the persuading pull within the framework of postmodernism, travel, third wave feminism and female bildungsroman. It also shows how women reinterpret and re-establish themselves to exist and survive and also reconstruct their own identity. Throughout the journey of the exploration of self, stories perform as a vehicle for representing women with the construction of new identity by using travel as a tool. This paper concludes by offering the most powerful impact of the narratives that has encouraged the value of movement and pause for the reflection of their own self. Alice Walker articulates, "During the pause is the ideal time to listen to stories (as) stories are capable of teaching us things we all used to know." (2006, p. 59). Travel narratives like The Shooting Star allow us to explore our inside self by uncovering the resolutions that may sound authentic for every individual subject. It shows how travelling to different parts of world allows a woman to resist her existing identity and to reconstruct a new self, something that the writer asserts thus:

....after all, we were not put on earth to be prisoners of an unpredictable future. We were put on earth to live our present with a fierce courage, that when the future comes we can look it in the eye without a hint of fear and charm it with the adventures of past. (Nath, p. 151)

\section{References}

Butler, J. (1990). Gender Trouble: Feminism and the Subversion of Identity. Routledge.

Carrillo Rowe, A. (2009). Subject to power: Feminism without victims. Women's Studies in Communication, 32, 12-35.

De Beauvoir, S. (1989). The Second Sex. 1952. Trans. HM Parshley. New York: Vintage Books.

Foss, S. K., \& Foss, K. A. (2011). Constricted and constructed potentiality: An inquiry into paradigms of change. Western Journal of Communication, 75(2), 205-238.

Fraiman, S. (1993). The Mill on the Floss, the Critics, and the Bildungsroman. Publications of the Modern Language Association of America, 136-150.

Frank, A. W. (1995). The Wounded Storyteller: Body, Illness, and Ethics. Chicago: University of Chicago Press.

Hammers, M. (2005). Cautionary tales of liberation and female professionalism: The case against Ally McBeal. Western Journal of Communication, 69, 167-182.

Hariharan, G. (2008). When Dreams Travel. Penguin Books India.

Kearney, H. R. (1979). Feminist challenges to the social structure and sex roles. Psychology of Women Quarterly, 4(1), 16-31. 
Nath, S. (2018). The Shooting Star: A Girl, Her back and the World. Penguin Random House India.

Reich, J. (1996). CAROL LAZZARO-WEIS." From Margins to Mainstream: Feminism and Fictional Modes in Italian Women's Writing, 1968-1990"(Book Review). Italica, 73(1), 128.

Roberson, S.L.(2009). American women and travel writing. In Bendixen, A., \& Hamera, J. (Eds.). The Cambridge Companion to American Travel Writing. Cambridge University Press. pp.214-227.

Thompson, C. (2011). Travel Writing. London: Routledge.

Walker, A. (2006). We Are The Ones We Have Been Waiting For: Inner Light in a Time of Darkness. New York: The New Press.

Westgate, C. J. (2009). Postmodern theory. In Encyclopedia of Communication Theory, Thousand Oaks, CA: Sage, $772-777$

Akshita Chotia is currently a Research Scholar in Banasthali University, Rajasthan. Her Research area includes Self, Travel Writing and Female Bildungroman. She was recently awarded an Exchange Student Fellowship at University of Education, Weingarten, Germany. 